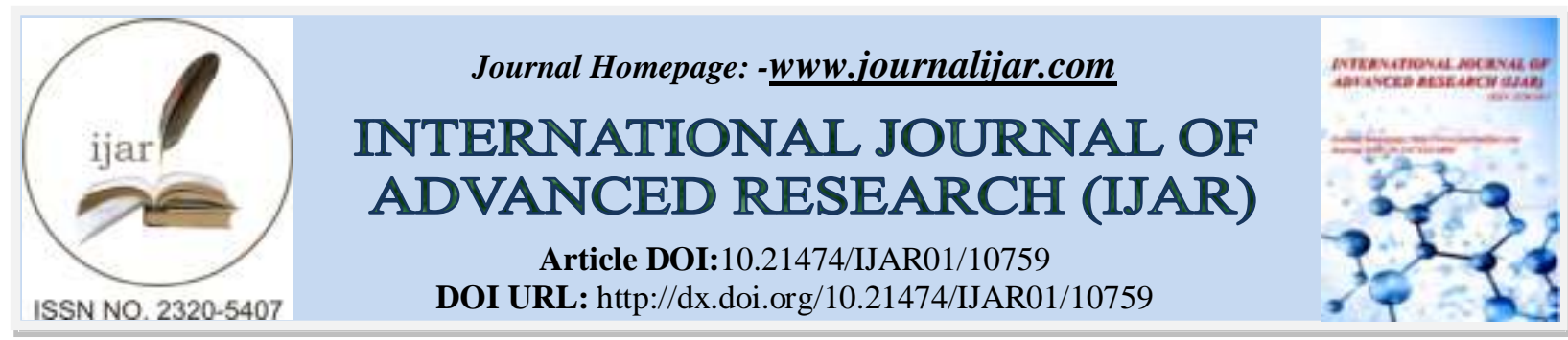

RESEARCH ARTICLE

\title{
MAGNETIC MICROSPHERE AS NOVEL DRUG DELIVERY SYSTEM: A REVIEW
}

\section{Ranjana Shaw ${ }^{1}$ and Tamalika Chakraborty ${ }^{2}$}

1. Post Graduate Student, Department of Biotechnology, Guru Nanak Institute of Pharmaceutical Science \& Technology, 157/F, Nilgunj Road, Panihati, Kolkata-700114, West Bengal.

2. Assistant Professor, Department of Biotechnology, Guru Nanak Institute of Pharmaceutical Science \& Technology, 157/F, Nilgunj Road, Panihati, Kolkata-700114, West Bengal.

\section{Manuscript Info}

\section{Manuscript History}

Received: 05 February 2020

Final Accepted: 07 March 2020

Published: April 2020

\section{Key words:-}

Novel Drug Delivery, Magnetic Microspheres, Microcarriers

\section{Abstract}

A therapeutic amount of drug at proper site in the body and its maintenance for a specific period of time are controlled by a welldesigned drug system. A number of drug delivery systems hold great promises for achieving the goal of controlled and site specific drug delivery, one of them is magnetic microsphere, a novel drug delivery system. Novel drug delivery system has been advanced to achieve controlled and targeted drug delivery to meet the needs of the body during the period of treatment. Magnetic microsphere, a newer approach in pharmaceutical field is magnetically controlled releasable supramolecular particles having a particle size ranging from 1-1000 $\mu \mathrm{m}$. A number of limitations facing current methods of delivering medicines areovercome by using a novel approach of magnetic drug delivery which uses engineered 'microcarriers'. Magnetic microsphere drug delivery system is captured in microvessels and dragged into adjacent tissues by magnetic field of below 1.0 tesla. Magnetic responses are received by magnetic carriers to a magnetic field from incorporated materials like chitosan, dextran etc. that are used for magnetic microspheres. Various carrier materials can be used in magnetic microsphere, one of the most utilized is serum albumin from human. Thus, the problem of conventional therapy can be overcome by a well-designed controlled drug delivery system. Microsphere drug delivery system has eminent importance as it has wide applications ranging from drug targeting at a specific site to imaging the diagnostic features and also in targeting tumours using anticancer drugs. It is more stable than liposomes, offering an advantage over it. The review shall include definitions, concepts, types, characteristics, advantage as well as methods and techniques used in preparations; it will also entail various applications and future prospects of magnetic microspheres as a novel drug delivery system.

Copy Right, IJAR, 2020,. All rights reserved.

\section{Introduction:-}

The most preferable route for taking medications is the oral route drug administration, the simplest, convenient and safest means of drug administration. However, an unconventional dosage form, the oral administration of most of 
the drugs possesses some limitations due to their short circulating half-life and restricted absorption via a defined segment of intestine. To overcome this, various approaches are in use for delivering a therapeutic substance to the target site in a sustained controlled release fashion. One such approach for obtaining maximum therapeutic efficacy is the use of microspheres as carriers for drug. One of the most interesting field of research in pharmaceutical science is the development of new delivery system for the controlled release of drugs through which maximum therapeutic efficacy can be achieved by delivering the agent to the target tissue in the optimal amount in right period of time thereby causing minimal side effects and little toxicity. The release of drug in a controlled and site specific manner is achieved by Novel drug delivery system which aims to deliver the drug at a rate directed by the needs of the body during the period of treatment to achieve controlled and targeted drug delivery. Microsphere based drug delivery system being one of them. Many types of drugs with small molecules, proteins and nucleic acids can be encapsulated by microsphere and are easily administrated through a syringe needle. They can give high bioavailability, nontoxic, normally biocompatible and are capable of constant release for long period of time, thus overcoming two major problems encountered in drug targeting namely reticuloendothelial clearance and target site specificity to reduce dosing frequency thereby improving patient compliance. Microspheres are classified as Bioadhesive microsphere, Magnetic microsphere, Floating microsphere, Radioactive microsphere, Polymeric microsphere (Biodegradable Polymeric microsphere, Synthetic Polymeric microsphere) of which Magnetic microsphere is the most efficient.

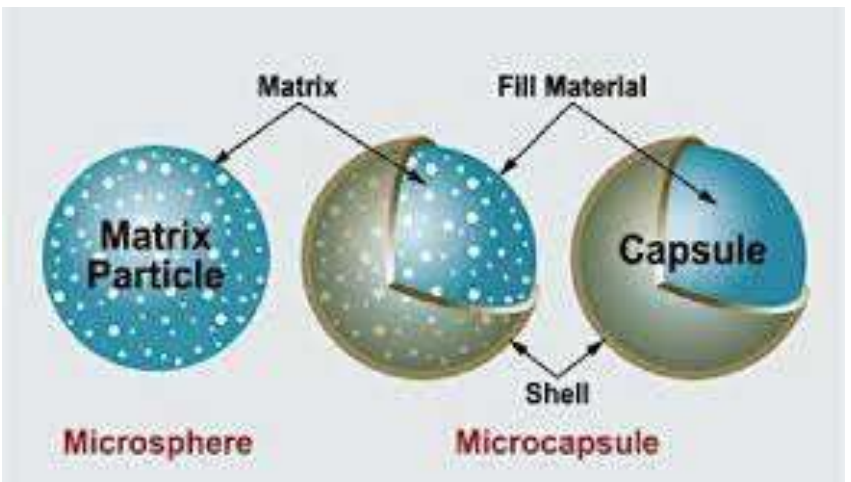

Magnetic microsphere, a newer approach in pharmaceutical field is magnetically controlled releasable supramolecular particleshaving a particle size ranging from 1-1000 $\mu$ mwhich uses engineered 'microcarriers'. Magnetic microsphere drug delivery system is captured in microvessels and dragged into adjacent tissues by magnetic field of below 1.0 tesla. Magnetic responses are received by magnetic carriers to a magnetic field from incorporated materials like chitosan, dextran etc. that are used for magnetic microspheres. Magnetic microspheres are prepared by phase separation emulsion polymerization (PSEP) method and continuous solvent evaporation (CSE) method. The magnetic microsphere's amount and rate of drug delivery can be regulated by varying size of microsphere, magnetic content, drug content, hydration state and drug release characteristic of carrier. Similarmethods like non-radioactive spheres are applied to magnetic radioactive microspheres. Outside the body,a magnet is placed which can be contained in an equipment that looks like an open magnetic resonance imaging scanner or simply a rod-shaped permanent magnet of any size directed to the target site. The loaded microspheres are introduced into a blood vessel and gather at a site to emit radiations that kills cancer cells. This therapeutic action takes weeks or sometimes gets completed in a couple of days depending on material used. Moreover, magnetic cores constitutes the magnetic polymer microsphere which ensures a strong magnetic response and polymeric shells to provide favourable functional groups, thus protecting particle aggregation. Magnetite content of microsphere plays an important role in drug delivery as they are well tolerated by the body, magnetic fields are supposed to be harmless to biological system and are adaptable to any part of the body.Many unique features are exhibited by these microspheres which are small and of uniform size,differ in shapes and morphologies and have wide applications in fields like diagnostics, molecular biology, drug targeting,cell proliferation,enzyme immobilization and radioimmunoassay.

\section{History of Magnetic carriers:}

1. A seminar paper was published by Gilchrist on the selective inductive heating of lymph nodes after injection of 20.100 nmsized magnetite particles into the lymph nodes near surgically removed cancer in 1956.

2. The radiofrequency heating method with embolization therapy was combined by Turner and rand. 
3. Descriptionof ability of magnetic carriersto accumulate small iron particles intravenously injected into the leg veins of dogs, using a large, externally applied horse shoe magnet was given by Meyers.

4. Hilal engineered magnetic endcatheters andgave description on their use to deposit and selectively embolize arterio-venous malformations with small magnets. For the embolization therapy of liver cancer, magnetic particles are used.

5. Widder proposed that at the end of the 1970s, defined spherical microspheres were made for the first time.Their magnetic albumin microspheres worked well as magnet resonance contrast and animal experiments for tumor therapy.

\section{Principleofmagneticmicrospheresdrugtargeting:}

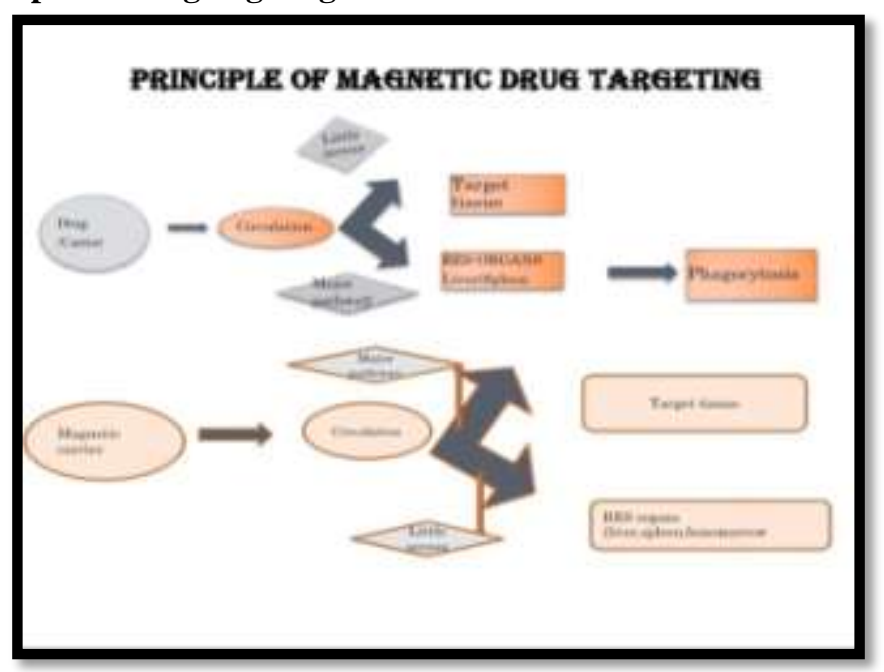

It is an efficient method of drug delivery in which drug is delivered to a localized disease siteby particulate carriers. The aim of specific targeting is efficiency of drug targeting should be enhanced; toxicity and side effects should be reduced at the same time. A therapeutic radioisotope or drug is encapsulated in a magnetic compound,injected into patient's blood stream and then stopped with a powerful magnetic field in the target area.The drug is slowly released from magnetic carriers or confers a local effect depending on the type of drug, thus it reduces the loss of drug as freely circulating in the body. A specific form of drug delivery where the drug is directed to its site action or absorption is known as drug targeting.This could be a cell, a particular organ structure, tissue or even an intercellular region. Accumulation efficiency of magnetic carrier on physiological carrier depends on certain physiological parameters e.g. particle size, surface characteristic, field strength and blood flow rate etc. It is possible to achieve high concentration of chemotherapeutic agents near the target agent without any toxic effect and thus reaching several fold increased drug levels.

\section{Magnetic properties:}

Bio separation includes magnetic particles which consist of one or more magnetic coreswith a coating matrix of polymers, hydroxyl apatite with terminal functionalized groups. Generally,the magnetic coreconsists either of magnetite $\left(\mathrm{Fe}_{3} \mathrm{O}_{4}\right)$ or magnetite $\left(\mathrm{gamma} \mathrm{Fe}_{2} \mathrm{O}_{3}\right.$ ) with super paramagnetic or ferromagnetic properties.Magnetic cores can also be made with magnetic ferrites, such as manganese ferrite or cobalt ferrite. A single-domainparticle's dipole moment fluctuates rapidly in the core because of the thermal excitation so that there is no magnetic moment for macroscopic time scaleis known as Superparamagnetism. Thus, when an external magnetic field is applied these particles are non magnetic.

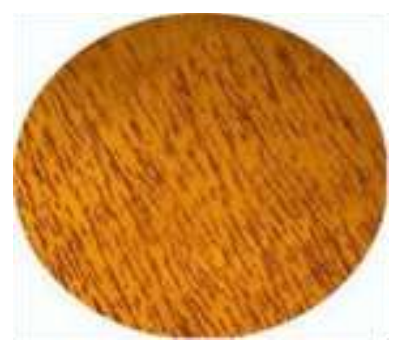

Figure 1:- Superparamagnetic particles under the influence of external magnetic field. 


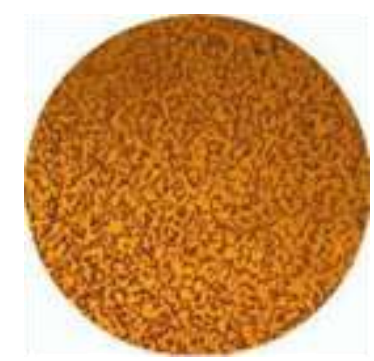

Figure 2:- Superparamagnetic particles under the absence of an external magnetic field,monodisperse particles distribution.

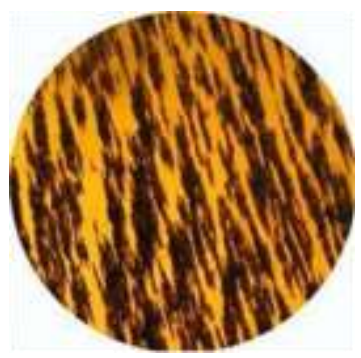

Figure 3:- Ferromagnetic particles under the influence of an external magnetic field.

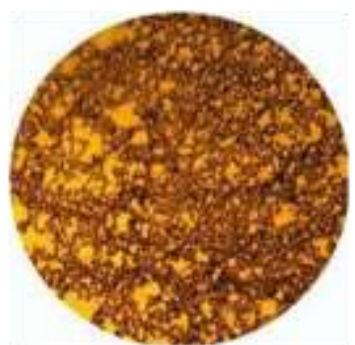

Figure 4:- Ferromagnetic particles in absence of an external magnetic field.

Those particles which are having a permanent mean magnetic moment are referred to as the ferromagnetic particles. Here, thelarger effective magnetic anisotropy is suppressed by the thermally activated motion of the core moment.For automaticDNA/RNAseparation/purification, generally the superparamagnetic andferromagnetic particles are recommended. For example, automaticDNA/RNA separation/ purificationsuch as genomic DNA, plasmid DNA, total RNA and PCR products, K-DNA and SiMAG/MP-DNA beads have been developed. The superparamagneticSiMAG/K-DNA beads and the ferromagnetic SiMAG/MP-DNAbeads are most suited for automatic DNA/RNA separation/purification havingexcellent magnetic properties. Since different processing methods work withdifferentrobot systems, either ferromagnetic SiMAG-DNA or superparamagneticbeads will lead to optimal results.

\section{Types of Magnetic Microspheres (Farah, 2017):}

Magnetic responses are received by magnetic carriers to a magnetic field fromincorporated materialsuch as chitosan, dextran etc.that are used for magnetic microspheres.Magnetic microspheres include the following types:

1. Therapeutic microspheres-For delivering chemotherapeutic agent to liver tumor, it is used. This system can also target drugs like proteins and peptides.

2. Diagnostic microspheres-It can be used to distinguish bowel loops from other abdominal structures by forming nanosize particles supra-magnetic iron oxides and for imaging metastases.

\section{Materials used in Magnetic Microspheres:}

1. Synthetic polymers.

2. Biodegradable: Epoxypolymers, Glycolides.

3. Non-biodegradable:Lactides, polyanhydrides.

4. Polymethylmetharylate, Acrolein. 
5. Natural polymers.

6. Proteins: Albumin, Collagen, Gelatin.

7. Carbohydrates: Agarose, Chitosan, Starch.

8. Chemically modified carbohydrate:Polystarch, Polydextran.

\section{Characterization of magnetic microspheres:}

1. Detection of particle size of microsphere:

Itcan be determined by using anoptical microscope.Here, size of total 100 particles were measured and then the average of these particles was taken as average particle size.

\section{Surface characterization:}

Surface characterization can be determined by using:

1. High-resolution microscopy

2. Scanning electron microscopy (SEM)

\section{Surface charge analysis:}

They can be achieved by using:

1. Micro electrophoresis

2. Laser Doppler anemometry

\section{Density:}

Its determination is done by pouring accurately weighed microspheres in measuring cylinder and to from a stable height it is tapped 100 times. Then the tapped volume is determined and finallycalculation of tapped density is done.

\section{Bulk density:}

Its determination is done by pouring accurately weighed microspheres in measuring cylinder and thus its bulk volume is determined.

\section{Flow properties:}

Flow properties are measured by following ways:

a. Angle of repose:It is the angle that a static heap of particles makes with the horizontal. Determination of flow properties of microspheres can be determined by fixed funnel flow method, from where calculation of angle of repose is done.

b. Hausner ratio:Its determination is from the ratios of tapped density and bulk density.

\section{Hardness:}

The force which is required for breaking the microsphere is termed as hardness.Monsanto hardness apparatuscan be used for testing hardness.

\section{Friability:}

For determination of friability, rosche friabilator is used.

\section{Methods of Preparation of Magnetic Microspheres:}

i. Solvent evaporation method:

Synthesis of polymer encapsulated microsphere is done by continuous solvent evaporation technique. Addition of a solution of polymer, drug and magnetite is donewith a volatile organic solvent, which when stirred forms auxiliary solution. Then homogenization of resultingsolution is done and stirred at a temperature in the range of $22-30^{\circ} \mathrm{C}$. Thenseparation of formed magnetic microsphereis done by centrifugation. Lastly, the product is freeze-dried \& stored at $4^{\circ} \mathrm{C}$.

\section{ii. Multiple emulsion method:}

This method comprises of the formation of the multiple emulsions of type w/o/w which is best suited to water soluble drugs, peptides, proteins and vaccines. This method can be used with both natural and synthetic polymers. In a lipophilic organic continuous phase,the aqueous protein is then dispersed.May be the active constituents are the contents of this protein solution. The polymer solution that eventuallyencapsulates the protein contained in dispersed aqueous phase is generally the constituent of the continuous phase. Before addition to the aqueous solution of the 
poly vinyl alcohol, primary emulsion is subjected to homogenization or sonication.As a result, multiple emulsionsare formed. Then, either by solvent evaporation or by solvent extraction, solvent removal takes place.Successful incorporation of microspheres using this method includes hydrophilic drugs like indomethacin, leutinizing hormoneand conventional molecules.

\section{iii. Phase separation emulsion polymerization method:}

Addition of the aqueous solution of polymer, drug and magnetite with vegetable oil is done and is then emulsified using a magnetic stirrer. As a result, the emulsion isstabilized by heating at the temperature $\left(100-150^{\circ} \mathrm{C}\right)$.Thendrop wise,thecross-linking agent is added into the emulsion with continuous stirring.Then, the separation of formed magnetic microsphere is done from oil by washing procedures. Thus, product formed and freeze-dried and stored at $44^{\circ} \mathrm{C}$.

iv. Emulsion solvent extraction method:

The dispersion of an aqueous phase, containing a water-soluble homo-polymer and magnetite nanoparticles into droplets in an organic medium using an amphiphilic block copolymer which serves as the dispersant. Water distillation at a raised temperature from the aqueous droplets to yield polymer magnetite particles follows this. A reagentthen locks the structure of the particleswhich was being added to the water-soluble copolymer block and homo-polymerfor cross-linking.

\section{v. Hot melt microencapsulation:}

This method comprises of melting of polymer and then mixing of it with solid drug particles that have beensieved to less than $50 \mu \mathrm{m}$. In a non-miscible solvent (like silicone oil), the mixture is suspended and continuously stirred, and then heated to $5^{\circ} \mathrm{C}$ above the melting point of the polymer. The stabilization of emulsionis done, then it is cooled till the solidification of polymer particles.As a result, through decantation, microspheres are washed with petroleum ether. The development of a process suitable for the water labile polymers, e.g. polyanhydrides for microencapsulation is the primary objective of this method.Alteration of stirring rate can easily control size distribution of microspheres with diameter of $1-1000 \mu \mathrm{m}$. Exposure of the drug at moderate temperature is the only disadvantage of this method.

\section{vi. Dispersion copolymerization:}

The reaction of various monomers at the interface betweenthe two immiscible liquid phases for formation of a film of polymer envelops the dispersed phase.Two reacting monomers are employed in this technique, one of which is dispersed in the continuous phase and other is dissolved in continuous phase. Example: Amphiphilic magnetic microsphere in the range of 5 to $100 \mu \mathrm{m}$.

vii. Microwave-assisted preparation of magnetic albumin microspheres:

Preparation of magnetic bovine albumin microsphere is done by this method.Smaller particles are produced through this method, being faster than traditional methods. Synthesis of magnetized protein microsphere can be done through this method.

Table showing drugs and their polymers used in drug delivery (Batra,Singh,Nautiyal, 2013):

\begin{tabular}{|l|l|l|l|l|l|l|}
\hline $\begin{array}{l}\text { Sl. } \\
\text { no }\end{array}$ & Drug & Polymer & Application & Method used & Target site & Reference \\
\hline 1 & Yttrium-90 & $\begin{array}{l}\text { Human } \\
\text { serum } \\
\text { albumin }\end{array}$ & $\begin{array}{l}\text { Bimodal } \\
\text { radionuclide- } \\
\text { hyperthermia } \\
\text { cancer } \\
\text { therapy }\end{array}$ & $\begin{array}{l}\text { Modified } \\
\text { emulsification } \\
\text { heat stabilization }\end{array}$ & Tumor cells & $\begin{array}{l}\text { (Wunderlich, } \\
2010)\end{array}$ \\
\hline 2 & Oxantrazole & Chitosan & $\begin{array}{l}\text { Cancer } \\
\text { therapy }\end{array}$ & $\begin{array}{l}\text { Emulsion/polymer } \\
\text { cross-linking/ } \\
\text { solvent } \\
\text { evaporation }\end{array}$ & Tumor cells & (Hassan,1992) \\
\hline 3 & Piperacillin/tazobactam & Dextran & $\begin{array}{l}\text { Antimicrobial } \\
\text { activity } \\
\text { against } \\
\text { aureus }\end{array}$ & $\begin{array}{l}\text { Continuous } \\
\text { solvent } \\
\text { evaporation }\end{array}$ & $\begin{array}{l}\text { Bind } \\
\text { penicillin- } \\
\text { binding proteins } \\
\text { (pbps) located } \\
\text { inside the } \\
\text { the }\end{array}$ & $\begin{array}{l}\text { (Kang \&Koh, } \\
\text { \&b87) }\end{array}$ \\
\hline
\end{tabular}




\begin{tabular}{|c|c|c|c|c|c|c|}
\hline & & & & & $\begin{array}{ll}\text { bacterial cell } \\
\text { wall }\end{array}$ & \\
\hline 4 & Aclarubicin & Gelatin & $\begin{array}{l}\text { Intravascular } \\
\text { tumour } \\
\text { targeting }\end{array}$ & $\begin{array}{l}\text { Water in oil } \\
\text { emulsion } \\
\text { polymerization }\end{array}$ & $\begin{array}{l}\text { Bind to minor } \\
\text { DNA } \\
\text { groove(DNA } \\
\text { intercalation) }\end{array}$ & $\begin{array}{l}\text { (Kang \&Koh, } \\
1987)\end{array}$ \\
\hline 5 & 5-Fluorouracil & $\begin{array}{l}\text { Bovine } \\
\text { serum } \\
\text { albumin } \\
\text { (BSA) }\end{array}$ & $\begin{array}{l}\text { Tumor of } \\
\text { hepatoma }\end{array}$ & $\begin{array}{l}\text { Emulsion- } \\
\text { ultrasound heat } \\
\text { stabilization }\end{array}$ & $\begin{array}{l}\text { Binds to the } \\
\text { nucleotide- } \\
\text { binding site of } \\
\text { Thymidylate } \\
\text { synthase }\end{array}$ & $\begin{array}{l}\text { (Kaixiong, } \\
\text { 1999) }\end{array}$ \\
\hline 6 & Adriamycin & Albumin & $\begin{array}{l}\text { Cytotoxic } \\
\text { effect on } \\
\text { tumor cells }\end{array}$ & $\begin{array}{l}\text { Heat-stabilized } \\
\text { protein methods }\end{array}$ & $\begin{array}{l}\text { Interacts with } \\
\text { DNA } \\
\text { by intercalation }\end{array}$ & $\begin{array}{l}\text { (Kaixiong, } \\
\text { 1999) }\end{array}$ \\
\hline 7 & Diclofenac & Gelatin & $\begin{array}{l}\text { Reduced joint } \\
\text { swelling }\end{array}$ & $\begin{array}{l}\text { sodium } \\
\text { Emulsification } \\
\text { and cross linking }\end{array}$ & $\begin{array}{l}\text { Bind to the } \\
\text { enzyme that } \\
\text { makes } \\
\text { prostaglandins } \\
\text { (cyclooxygenase) } \\
\text { thereby blocking } \\
\text { it }\end{array}$ & (Surini,2009) \\
\hline 8 & Amphotericin B & Albumin & $\begin{array}{l}\text { Treatment of } \\
\text { visceral } \\
\text { leishmaniasis }\end{array}$ & Spray drying & 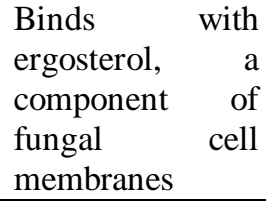 & $\begin{array}{l}\text { (Brunete, } \\
\text { 2004) }\end{array}$ \\
\hline
\end{tabular}

Advantages of Magnetic Microspheres(Farah, 2017):

1. Only small fraction of the free drug dose can achieve therapeutic responses in targetorgans.

2. Patient compliance is improved by reducing dosing frequency.

3. This method ensures prolonged therapeutic effect within target tissues.

4. A controllable variability in drug release is allowed by microsphere morphology.

\section{Disadvantages of Magnetic Microspheres(Farah, 2017):}

1. This technique is expensive and specialized manufacture and quality control system is required.

2. For targeting and monitoring,a specialized magnet is needed.

3. Permanent deposit of large fraction of magnetite in tissues occurs which usually gets entrapped in carriers.

4. Generally,controlled release formulations consist of higher drug load and thus potential toxicity occurs if any loss of integrity of the release characteristics of the dosage form happens.

\section{Applications of Magnetic Microspheres:}

1. Considerable attention is achieved by magnetic microspheres as it possesses wide applications in the field of bioengineering and biomedical. Examples include enzyme immobilization,protein purification,targeting drugs etc.

2. Therapeutic agents are delivered through magnetic field gradient. This ensures site specificity of drug thereby eliminating systemic drug side effects.

3. Stem cell extraction and bone marrow purging uses magnetic microspheres.

4. Nowadays, magnetic microsphereshave been used as carriers for binding proteins, enzymes and drugs showing a major impact in various fields of biotechnology and medicine.

5. For bacteria detection,Streptavidin coated magnetic beads are used.

6. For specific cell labelling,magnetic polystyrene microsphere is used.

7. For detection of metastases in non-enlarged lymph nodes, supra-magnetic iron oxide microsphere is used.

8. For detection of isolated breast carcinoma cells in bone marrow and peripheral blood, magnetic dynabeads are used. 


\section{Future Prospects:}

The area of medicinal field shows bright future prospects of magnetic microspheres as it has wide spectrum of application in molecular biology,e.g. microsphere based genotyping platform is used for detecting six single nucleotide polymorphism, to prevent tumor, yittrium-90.It can be expected that in near future,magnetic particles would be used as a detection probe for a variety of assays,such as fluorescence, radioactivity and chemiluminescence. Future work shall involve development of detection method for bio-molecular interaction using magnetic particles as label.Special emphasis through this technique is shown in microarray technology, where basis for determining gene expression or allelic variation are bio-molecular interactions like cDNA-mRNA or DNADNA.

\section{Conclusion:-}

Magnetic microspheres are observed as the best novel drug delivery system possessing the advantage of target specificity and better patient compliance. It shows enormous applications as they are not only used for delivering drugs but also for detecting bio-molecular interaction and imaging tumor etc. So,magnetic microspheres in future will find the central place in novel drug delivery,particularly in diseased cell sorting, diagnostics, safe, targeted and effective in vivo delivery and supplements as miniature versions of diseased organs and tissues in the body.It can also be expected that many patent dosage forms can be obtained in the form of magnetic microspheres in future.

\section{References:-}

1. Kakar S, Batra D, Singh R, Nautiyal U. Magnetic microspheres as magical novel drug delivery system: A review. Journal of Acute Disease. 2013;1:12.

2. Myzak, M. C., Karplus, P. A., Chung, F.-L., \&Dashwood, R. H. (2004). A Novel Mechanism of Chemoprotection by Sulforaphane. Cancer Research, 64(16), 5767-5774. doi: 10.1158/0008-5472.can-04-1326

3. Patel, J.K., Patel, R.P., Amin, A.F. and Patel, M.M., 2005. Formulation and evaluation of mucoadhesiveglipizide microspheres. AApsPharmSciTech, 6(1), pp.E49-E55.

4. Berensmeier, Sonja. (2007). Magnetic Particles for the Separation and Purification of Nucleic Acids. Applied microbiology and biotechnology. 73. 495-504. 10.1007/s00253-006-0675-0.

5. Sahil, Kataria\&Akanksha, Middha\&Premjeet, Sandhu\&Bilandi, Ajay \& Kapoor, Bhawana. (2011). Microsphere: A Review. International Journal of Research in Pharmacy and Chemistry. 1.

6. Alagusundaram M, Madhu C, Umashankari K, Attuluri B, Lavanya C, Ramkanth S. Microspheres: As novel drug delivery system. International Journal of Chem Tech Research. 2009; 1(3): 526-534

7. M Sam, D Gayathri, V Prasanth, B Vinod. NSAIDs as Microspheres. The Internet Journal of Pharmacology. 2007 Volume 6 Number 1.

8. Chen, C.-Y., Long, Q., Li, X.-H., \&Xu, J. (2008). Microwave-assisted Preparation of Magnetic Albumin Microspheres. Journal of Bioactive and Compatible Polymers, 23(5), 490-500.

9. Patel, N.R., Patel, D.A., Bharadia, P.D., Pandya, V.M., \&Modi, D. (2011). Microsphere as a novel drug delivery.

10. N.K.Jain, Controlled and Novel drug delivery, 04 Edition, 236-237, 21.

11. Surini, S., Anggriani, V., \& Anwar, E. (2009). Study of Mucoadhesive Microspheres Based on Pregelatinized Cassava Starch Succinate as a New Carrier for Drug Delivery. Journal of Medical Sciences(Faisalabad), 9(6), 249-256. doi: 10.3923/jms.2009.249.256

12. Sánchez-Brunete, J. A., Dea, M. A., Rama, S., Bolás, F., Alunda, J. M., Raposo, R., Méndez, M. T., TorradoSantiago, S., \&Torrado, J. J. (2004). Treatment of experimental visceral leishmaniasis with amphotericin B in stable albumin microspheres. Antimicrobial agents and chemotherapy, 48(9), 3246-3252.

13. Kaixiong, T., Daoda, C., Jianying, C. et al. Preparation of adriamycin magnetic albumin microspheres and their experimental antitumor effectsin vitro andinvivo. Journal of Tongji Medical University 19, 295-299 (1999).

14. Grumezescu, Alexandru\&Ficai, Anton \&Ficai, Denisa\&Predan, Gentiana\&Chifiriuc, Mariana. (2012). Polymeric magnetic silica microspheres as a drug loader for antimicrobial delivery substances. DIGEST JOURNAL OF NANOMATERIALS AND BIOSTRUCTURES. 7. 1891-1896.

15. Lee, Kang \&Koh, Ik. (1987). Intravascular tumour targeting of aclarubicin-loaded gelatin microspheres. Preparation, biocompatibility and biodegradability. Arch. Pharm. Res. 10. 42-49. 10.1007/BF02855620.

16. Hassan, Emad\& Parish, Roy \& Gallo, James. (1992). Optimized Formulation of Magnetic Chitosan Microspheres Containing the Anticancer Agent, Oxantrazole. Pharmaceutical research. 9. 390-7. 10.1023/A:1015803321609. 
17. Wunderlich, Gerd\& Schiller, Eik\& Bergmann, Ralf \&Pietzsch, Hans-Jürgen. (2010). Comparison of the stability of Y-90-, Lu-177- and Ga-68- labeled human serum albumin microspheres (DOTA-HSAM). Nuclear medicine and biology. 37. 861-7. 10.1016/j.nucmedbio.2010.05.004.

18. Izmaĭlov, A \&Kiselev, M \&Vakurov, Alex \&Gladilin, A \&Levashov, Andrey. (2000). Alpha-chymotrypsin immobilized on ferromagnetic particles coated with titanium oxide: production and catalytic properties. Prikladnaiabiokhimiia i mikrobiologiia. 36. 68-73.

19. Surini, S., Anggriani, V., \& Anwar, E. (2009). Study of Mucoadhesive Microspheres Based on Pregelatinized Cassava Starch Succinate as a New Carrier for Drug Delivery. Journal of Medical Sciences(Faisalabad), 9(6), 249-256. doi: 10.3923/jms.2009.249.256

20. Farah, Farah. (2017). MAGNETIC MICROSPHERES: A NOVEL DRUG DELIVERY SYSTEM. World Journal of Pharmacy and Pharmaceutical Sciences. 93-112. 10.20959/wjpps20179-10054

21. Sharma, D., \& Sharma, A. (2017). Magnetic Microsphere An Emerging Drug Delivery System. Asian Journal of Pharmaceutical and Clinical Research, 10(6), 54. doi: 10.22159/ajpcr.2017.v10i6.17284

22. Asmatulu, R., Zalich, M. A., Claus, R. O., \& Riffle, J. S. (2005). Synthesis, characterization and targeting of biodegradable magnetic nanocomposite particles by external magnetic fields. Journal of Magnetism and Magnetic Materials, 292, 108-119. doi: 10.1016/j.jmmm.2004.10.103

23. Vyas, S. P., \&Khar, R. K. (2004). Targeted \& controlled drug delivery: Novel carrier systems. New Delhi, India: CBS Publishers \& Distributors.

24. Johansen, L., Nustad, K., Ørstavik, T. B., Ugelstad, J., Berge, A., \&Ellingsen, T. (1983). Excess antibody immunoassay for rat glandular kallikrein. Monosized polymer particles as the preferred solid phase material. Journal of Immunological Methods, 59(2), 255-264. doi: 10.1016/0022-1759(83)90038-8

25. Chien, Y. W. (1992). Novel drug delivery systems. New York u.a.: Dekker.

26. Ito, A., Shinkai, M., Honda, H., \& Kobayashi, T. (2005). Medical application of functionalized magnetic nanoparticles. Journal ofbioscience and bioengineering, 100(1), 1-11.

27. Forni, F., Vandelli, M. A., \&Cameroni, R. (1992). Influence of drug loading level on drug release and dynamic swelling of crosslinkedgelatin microspheres. Journal of microencapsulation, 9(1), 29-39

28. Aggarwal, A., Chhajer, P., \&Maheshwari, S. (2012). Magnetic drug delivery in therapeutics. International Journal of Pharmaceutical Sciences and Research, 3(12), 4670.

29. Ho, E., Clarke, J. D., \&Dashwood, R. H. (2009). Dietary sulforaphane, a histone deacetylase inhibitor for cancer prevention. The Journal of nutrition, 139(12), 2393-2396

30. Ramteke, K. H., Jadhav, V. B., \& Dhole, S. N. (2012). Microspheres: As carrieres used for novel drug delivery system. IOSRPHR, 2(4), 44-48.

31. Prasad, S. G. B., Gupta, V. R. M., Devanna, N., \&Jayasurya, K. (2014). Microspheres as drug delivery systema review. JGTPS, 5(3), 1961-1972.

32. Vasir, J. K., Tambwekar, K., \&Garg, S. (2003). Bioadhesive microspheres as a controlled drug delivery system. International journal of pharmaceutics, 255(1-2), 13-32.

33. Pawan, C., \&Hemchand, P. (2009). Magnetic microsphere: as targeted drug delivery. Journal of Pharmacy Research, 2(5), 964-966.

34. Parodi, B., Russo, E., Caviglioli, G., Cafaggi, S., \&Bignardi, G. (1996). Development and characterization of a buccoadhesive dosage form of oxycodone hydrochloride. Drug Development and Industrial Pharmacy, 22(5), 445-450.

35. Saiyed, Z. M., Telang, S. D., \&Ramchand, C. N. (2003). Application of magnetic techniques in the field of drug discovery and biomedicine. BioMagnetic research and Technology, 1(1), 2.

36. Nacht S, Kantz M. The microsponge: A novel topical programmable delivery system. Top Drug Deliv Syst. 1992;42:299-325.

37. Asmatulu, R., Zalich, M. A., Claus, R. O., \& Riffle, J. S. (2005). Synthesis, characterization and targeting of biodegradable magnetic nanocomposite particles by external magnetic fields. Journal of Magnetism and Magnetic Materials, 292, 108-119.

38. Johansen, L., Nustad, K., Ørstavik, T. B., Ugelstad, J., Berge, A., \&Ellingsen, T. (1983). Excess antibody immunoassay for rat glandular kallikrein. Monosized polymer particles as the preferred solid phase material. Journal of immunological methods, 59(2), 255-264.

39. Nasra, M. K., Mohamed, M. M., Elblbesy, M. A., \&Hefney, B. A. (2011). Preparation of biocompatible magnetic microspheres with chitosan. Journal of Biomaterials and Nanobiotechnology, 2(02), 193.

40. Yeung, Y. A., \&Wittrup, K. D. (2002). Quantitative screening of yeast surface- displayed polypeptide libraries by magnetic bead capture. Biotechnology progress, 18(2), 212-220. 
41. Trivedi, P., Verma, A. M. L., \&Garud, N. (2014). Preparation and characterization of aceclofenac microspheres. Asian Journal of Pharmaceutics (AJP): Free full text articles from Asian J Pharm, 2(2).

42. Widder, K. J., Senyei, A. E., Ovadia, H., \& Paterson, P. Y. (1979). Magnetic protein A microspheres: a rapid method for cell separation. Clinical immunology and immunopathology, 14(3), 395-400.

43. Acter, S., Cho, J., Kim, J. W., Byun, A., Park, K. H., \& Kim, J. W. (2015). Synthesis and Shape Control of Uniform Polymer Microparticles by Tailored Adsorption of Poly (ethylene oxide)- b- Poly ( $\varepsilon$ - caprolactone) Copolymer. Bulletin of the Korean Chemical Society, 36(5), 1467-1473.

44. Gong, Z., Hueckel, T., Yi, G. R., \&Sacanna, S. (2017). Patchy particles made by colloidal fusion. Nature, 550(7675), 234-238.

45. Salimi, A. (2018). Liposomes as a novel drug delivery system: fundamental and pharmaceutical application. Asian Journal of Pharmaceutics (AJP): Free full text articles from Asian J Pharm, 12(01).

46. Rosenberg, R. T., \& Dan, N. R. (2011). Diffusion through colloidosome shells. Journal of colloid and interface science, 354(2), 478-482.

47. Yuan, Q., Cayre, O. J., Fujii, S., Armes, S. P., Williams, R. A., \& Biggs, S. (2010). Responsive Core-- Shell Latex Particles as Colloidosome Microcapsule Membranes. Langmuir, 26(23), 18408-18414.

48. Prajapati, V. D., Jani, G. K., \&Kapadia, J. R. (2015). Current knowledge on biodegradable microspheres in drug delivery. Expert opinion on drug delivery, 12(8), 1283-1299.

49. Senyei, A., Widder, K., \&Czerlinski, G. (1978). Magnetic guidance of drug- carrying microspheres. Journal of Applied Physics, 49(6), 3578-3583.

50. Foox, M., \&Zilberman, M. (2015). Drug delivery from gelatin-based systems. Expert opinion on drug delivery, 12(9), 1547-1563.

51. Cunha, L., Rodrigues, S., Rosa da Costa, A. M., Faleiro, L., Buttini, F., \&Grenha, A. (2019). Inhalable chitosan microparticles for simultaneous delivery of isoniazid and rifabutin in lung tuberculosis treatment. Drug development and industrial pharmacy, 45(8), 1313-1320.

52. Lim, S. T., Martin, G. P., Berry, D. J., \& Brown, M. B. (2000). Preparation and evaluation of the in vitro drug release properties and mucoadhesion of novel microspheres of hyaluronic acid and chitosan. Journal of Controlled Release, 66(2-3), 281-292.

53. Varshosaz, J., Ahmadi, F., Emami, J., Tavakoli, N., Minaiyan, M., Mahzouni, P., \&Dorkoosh, F. (2011). Microencapsulation of budesonide with dextran by spray drying technique for colon-targeted delivery: an in vitro/in vivo evaluation in induced colitis in rat. Journal of microencapsulation, 28(1), 62-73.

54. Kim, K. K., \& Pack, D. W. (2006). Microspheres for drug delivery. In BioMEMS and biomedical nanotechnology (pp. 19-50). Springer, Boston, MA.

55. Bergemann, C., Müller-Schulte, D., Oster, J. A., à Brassard, L., \&Lübbe, A. S. (1999). Magnetic ion-exchange nano-and microparticles for medical, biochemical and molecular biological applications. Journal of Magnetism and Magnetic Materials, 194(1-3), 45-52.

56. Gallo, J. M., Gupta, P. K., Hung, C. T., \& Perrier, D. G. (1989). Evaluation of drug delivery following the administration of magnetic albumin microspheres containing adriamycin to the rat. Journal of pharmaceutical sciences, 78(3), 190-194.

57. Ito, A., Shinkai, M., Honda, H., \& Kobayashi, T. (2005). Medical application of functionalized magnetic nanoparticles. Journal of bioscience and bioengineering, 100(1), 1-11.

58. Parmar, H., Bakliwal, S., Gujarathi, N., Rane, B., \&Pawar, S. (2010). Different methods of formulation and evaluation of mucoadhesive microsphere. International journal of applied biology and pharmaceutical technology, 1(3), 1157-1167.

59. KavitaKunchu, RajeVeera Ashwani; Albumin Microspheres: "A Unique system as drug delivery carriers for non steroidal anti-inflammatory drugs"; International research journal of pharmacy;2010;5(2):23-27.

60. Kataria S., Middha A., Sandhu P., Ajay B. and Bhawana K.; "Microsphere: A Review" International Journal of Research in Pharmacy and Chemistry ;2011, 1(4) 125-145. 